Animal, Poultry and Fish Production Research

http:/www.journals.zu.edu.eg/journalDisplay.aspx?Journalld=1\&queryType=Master

\title{
DETOXIFICATION OF DIETARY LEAD BY GARLIC POWDER IN BROILER CHICKS
}

\author{
Noura A. Ismail", A.M. El-Maghawry, F.M. Reda and M.S. El-Kholy \\ Poult. Dept., Fac. Agric., Zagazig Univ., Egypt
}

Received: 11/11/2018 ; Accepted: 26/11/2018

\begin{abstract}
A $2 \times 4$ factorial arrangement was performed including two levels of garlic powder (0 and $0.5 \%)$ and four levels of lead acetate $(0,300,600$ and $900 \mathrm{mg} / \mathrm{kg}$ diet). One hundred twenty unsexed 1-week-old Ross broiler chicks were randomly distributed to 8 dietary treatment groups (15 birds each). Each treatment was subdivided to 3 replicates and each replicate contained 5 chicks. Growth performance and carcass traits were studied. Obtained results showed that final live body weight, daily body weight gain, feed conversion ratio and survival rate were significantly $(\mathrm{p}<0.01)$ improved while, daily feed intake was significantly $(\mathrm{p}<0.01)$ decreased with dietary garlic supplementation. Lead acetate significantly $(\mathrm{p}<0.01)$ impaired live body weight, body weight gain and feed conversion. The interaction between lead levels and garlic supplementation showed that dietary garlic supplementation reversed these deleterious effects of lead intoxication on growth performance traits. Giblets percentage was significantly decreased with dietary supplementation by garlic and lead acetate at different levels, while, carcass and dressing were not affected significantly. These results suggested that garlic supplementation at $0.5 \%$ in broiler chicks diets can promotes growth performance traits and reverse the inhibitory effects of lead intoxication on such traits.
\end{abstract}

Key words: Lead acetate, broilers, garlic, growth performance.

\section{INTRODUCTION}

Lead is a common cause of poisoning in domestic animals throughout the world. However, lead poisoning can occur in all domestic animals including horses, poultry and dogs (Khan et al., 2008). Animals become intoxicated when they consume lead from contaminated feed and water. The main sources of contamination of feed by lead are soil, industrial pollution and agricultural technology as well as feed processing. A good source of lead contamination of poultry feed is bone and blood meals, majority of which comes from cattle. However, in cattle, highest lead accumulation has been reported to occur in bones (Heaney, 2000). Other sources of lead contamination are leaded gasoline fumes (Genevieve and Greg, 1994); paints used in Poultry equipment such as drinkers and feeders to prevent rusting, with either lead based paint

* Corresponding author: Tel. : +201010514306

E-mail address: Ibrahimeid087@gmail.com or lead-free paint with leaded drying agent. Also, majority of litter material that comes from woods previously painted with lead base paints (North and Bell, 1990). Lead has long been recognized as a poisons to living organisms, with negative effects on general health. Ingestion and inhalation are the most common entry routes of lead into animals. In many countries, lead poisoning continues to be a common occupational diseases affecting several organ systems (Hossain et al., 2014). Ingested lead has resulted in poisoning, poor performance and death in animals (McDowell, 1992; Gurer and Ercal, 2000). Erdogan et al. (2005) showed that $200 \mathrm{mg}$ lead/kg diet reduced growth in term of body weight and body weight gain. Bakalli et al. (1995) also reported that feed conversion ratio was significantly poor at a level of $10 \mathrm{mg}$ lead/ $/ \mathrm{kg}$ feed. Garlic contains more than 200 chemical compounds. Some of its more important ones include: Sulphur- containing 
compounds (allice, alliin and ajoene) and enzymes (allinase, peroxidase and myrosinase) protein, fiber and free amino acids. It also contains high levels of saponins, phosphorus, potassium, sulfur and zinc; moderate levels of selenium, Vitamamins A and C; and low level of calcium, magnesium, sodium, iron, manganese and Bcomplex Vitamamins (Mahaffy and Vanderveen, 1979). Most researchers agree that the sulfur containing compounds of garlic, especially allicin, alliin, cy-croalliin and diallyldisuphide are the most biochemically active. The lipid-soluble diallyl sulphide, diallyl sulphide (DADS) and dis ally1 sulphide (DATS), and water-soluble s-allylcysteine (SAC) and s-ally-mercaptocysteine (SAMC) are the major chemotherapeutic agents (Amagase $\boldsymbol{e t}$ al., 2001). Treatment of animals with natural product like garlic improves such toxic effect of lead acetate $(\mathrm{Pb})$. The protection action of garlic against $\mathrm{Pb}$ toxicity could be attributed by antioxidant action of its sulfhydryl groups (Ashour, 2002). The assumption of oxidative stress as a mechanism in $\mathrm{Pb}$ toxicity suggests that antioxidant action of garlic sulfhydryl groups might play a role in the treatment of $\mathrm{Pb}$ poisoning. So the present study was carried out to evaluate the ability of garlic powder to ameliorate the toxic effects of lead on growth performance and carcass traits in broilers chickens.

\section{MATERIALS AND METHODS}

This study was conducted at Poultry Research Farm, Poultry Department, Faculty of Agriculture, Zagazig University, Egypt. All the experimental procedures were carried out according to the Local Experimental Animal Care Committee and approved by the ethics of the institutional committee. Birds were cared for using husbandry guidelines derived from Zagazig University standard operating procedures.

A $2 \times 4$ factorial arrangement was performed included two levels of garlic $(0$ and $5 \mathrm{gm} / \mathrm{kg}$ diet) and four levels of lead acetate $(0,300,600$ and $900 \mathrm{mg} / \mathrm{kg}$ diet). A total number of 120 unsexed one week-old ross 300 were randomly assigned into 8 treatment groups, (15 chicks in each group). Each group of birds was subdivided into three replicates, each of 5 chicks. Each replicate was housed in one cage $(60 \times 60 \times 50$ $\mathrm{cm})$. The birds were received starter diet till 3 weeks of the age and finisher diet to 6 weeks of the age. The experiment of basal diets were formulated to cover the nutrient requirements for broilers chicks according to NRC (1994). Composition and calculated analysis of the basal diets was showed in Table 1.

Vaccination and medical program were done according to the different stages of age under supervision of a veterinarian. Chicks were grown in brooders with raised wire floors and were reared under the same managerial and hygienic conditions. The lighting pattern was 23 hr., light: $1 \mathrm{hr}$ dark. Feed and water were ad libitum throughout the experimental period (1-6 weeks of age). Birds were weighed individually at weekly intervals. Mortality was recorded daily. Feed consumption was measured per replicate weekly, and feed conversion ratio was obtained by dividing feed intake by weight gain (feed intake/weight gain).

At the end of the experiment (6 weeks of age), three chicks of each group were sampled randomly for carcass evaluations at 6 weeks of age, fasted overnight, weighed and slaughtered by sharp knife to complete bleeding, then weighed. Their feathers were plucked manually, eviscerated by hand. Whole carcass, abdominal fat pad (excluding the gizzard fat), empty gizzard, liver and heart were excised and weighed individually. The studied slaughter traits were carcass yields, giblets (liver, gizzard and heart) and dressing percent (carcass weight plus giblets weight) $\times 100$ /pre-slaughter weight $\mathrm{g}$.

Analysis of variance for data was accomplished using the SAS General Linear Models Procedure (SAS, 2002) on a $2 \times 4$ factorial arrangement basis according to (Snedcor and Cochran 1982) by adopting the following model:

$$
\mathrm{X}_{\mathrm{ijk}}=\mu+\mathrm{G}_{\mathrm{i}}+\mathrm{L}_{\mathrm{j}}+\mathrm{LG}_{\mathrm{ij}}+\mathrm{E}_{\mathrm{ijk}}
$$

Where:

$X_{\mathrm{ijk}}=$ the trait under study, $\mu=$ General mean, $G_{i}=$ Fixed effect of dietary garlic ( 0 and $5 \mathrm{~g} / \mathrm{kg}$ diet $), \mathrm{L}_{\mathrm{j}}=$ Fixed effect of dietary lead levels of energy $(0,300,600$ and $900 \mathrm{~g} / \mathrm{kg}$ diet $)$, $\mathrm{LG}_{\mathrm{ij}}=$ Interaction between garlic and lead, $\mathrm{E}_{\mathrm{ijk}}=$ Random error. Differences among treatment means within the same factor were tested using Duncan's New Multiple Range test (Duncan, 1955). All percentages were converted to the corresponding arcsine prior to statistical analysis. 
Table 1. Composition and calculated analysis of the experimental basal diets

\begin{tabular}{lcc}
\hline Ingredient & Starter diet (\%) (1-3) weeks & Finisher diet (\%) (3-6) weeks \\
\hline Yellow corn & 57.13 & 60.53 \\
Soybean meal 48\% & 31.65 & 27.15 \\
Corn gluten meal & 6.50 & 6.10 \\
Limestone & 1.24 & 1.15 \\
Di-calcium & 1.70 & 1.50 \\
Nacl & 00.30 & 0.30 \\
Methionine & 0.05 & 0.02 \\
lysine & 0.13 & 0.10 \\
Soya oil & 01.00 & 2.85 \\
Premix* & 00.30 & 0.30 \\
Total & $\mathbf{1 0 0 . 0 0}$ & $\mathbf{1 0 0 . 0 0}$ \\
Calculated analysis:** & & \\
Crude protein (\%) & 23.00 & 21.00 \\
ME (Kcal/kg diet) & 2951 & 3099 \\
Ca (\%) & 1.00 & 0.90 \\
Available P (\%) & 0.45 & 0.40 \\
Lysine (\%) & 1.20 & 1.05 \\
M+C (\%) & 0.83 & 0.74 \\
CF (\%) & 3.56 & 3.31 \\
\hline Vifmo & &
\end{tabular}

* Vitamins and premix, each $3.00 \mathrm{~kg}$ consist of: Vitam .A. $12000.000 \mathrm{IU}$; Vitam. $\mathrm{D}_{3}, 2000.000 \mathrm{IU}$; Vitam. E.10g; Vitam. k 2g; Vitam $B_{1}, 1000$ mg; Vitam. $B_{2}, 49$ g; Vitam. B 6105 g; Vitam $B_{12}, 10 \mathrm{mg}$; Pantothenic, $10 \mathrm{~g}$; Niacin 20 g, Folic acid, $1000 \mathrm{mg}$; Biotin , $50 \mathrm{~g}$; Fe, 30g ; Mn, 40g; Cu, 3g; Co,200 mg; Si, $100 \mathrm{mg}$ and $\mathrm{Zn}, 45 \mathrm{mg}$.

**Calculated according to NRC (1994).

\section{RESULTS AND DISCUSSION}

\section{Growth Performance}

The result presented in Table 2 show that final live body weight, daily body weight gain, feed conversion ratio and survival rate were significantly $(p<0.01)$ improved, while, daily feed intake was significantly $(p<0.01)$ decreased with dietary garlic supplementation. The beneficial effect of garlic on body weight and feed utilization may be results from its effect on improving nutrient digestibility and modulating the microbial content of gastrointestinal flora (Peinado et al., 2013). In this respect, Fadlalla et al. (2010) recorded a significant $(\mathrm{p}<0.05)$ improvement in feed conversion ratio of birds kept on a diet containing $0.3 \%$ garlic. Suriya et al. (2012) investigated the effect of powdered garlic, turmeric and cinnamon on the growth of broilers and indicated that garlic added at 2.5 $\mathrm{g} / \mathrm{kg}$ increased the live weight of broiler chickens by $5 \%$ and decreased feed conversion rate compared to the other groups. Aziz et al. (2016) recommended that garlic can be used as feed additives at level of ( $5 \mathrm{~g}$ garlic powder/ $\mathrm{g}$ ) to improve the overall performance of broiler chicks.

With regard to lead effect, results in Table 2 reveale that final live body weight, daily body weight gain and feed conversion ratio were 
Table 2. Growth performance traits (Mean \pm SE) of broiler chicks as affected by dietary supplementation with lead acetate, garlic powder and their interactions during 1-6 weeks of age

\begin{tabular}{|c|c|c|c|c|c|c|c|}
\hline \multicolumn{2}{|l|}{ Item } & $\begin{array}{c}\text { Initial live } \\
\text { body weight } \\
\text { (g/bird) } \\
\end{array}$ & $\begin{array}{c}\text { Final live } \\
\text { body weight } \\
\text { (g/bird) } \\
\end{array}$ & $\begin{array}{c}\text { body weight } \\
\text { gain (g/day/ } \\
\text { bird) }\end{array}$ & $\begin{array}{l}\text { Feed intake } \\
\text { (g/day/ } \\
\text { bird) }\end{array}$ & $\begin{array}{c}\text { Feed } \\
\text { conversion } \\
\text { ratio }(\%) \\
\end{array}$ & $\begin{array}{c}\text { Survival } \\
\text { Rate } \\
(\%) \\
\end{array}$ \\
\hline \multicolumn{2}{|c|}{$\begin{array}{l}\text { Dietary garlic levels } \\
\text { (g/kg diet) }\end{array}$} & NS & $* *$ & $* *$ & $* *$ & $* *$ & \\
\hline & 0.0 & $192.83 \pm 0.59$ & $1883.33 \pm 13.84$ & $48.30 \pm 0.40$ & $86.16 \pm 0.31$ & $1.79 \pm 0.02$ & 93.33 \\
\hline & 5.0 & $192.92 \pm 0.65$ & $1921.08 \pm 15.24$ & $49.38 \pm 0.44$ & $83.68 \pm 0.46$ & $1.70 \pm 0.02$ & 100 \\
\hline \multicolumn{2}{|c|}{$\begin{array}{l}\text { Lead acetate levels } \\
\text { (mg/kg diet) }\end{array}$} & NS & $* *$ & $* *$ & NS & $* *$ & \\
\hline & 0.0 & $193.00 \pm 1.21$ & $1976.17 \pm 11.52^{\mathrm{a}}$ & $50.95 \pm 0.34^{\mathrm{a}}$ & $85.08 \pm 0.50$ & $1.67 \pm 0.02^{\mathrm{b}}$ & 93.33 \\
\hline & 300 & $192.83 \pm 0.70$ & $1894.50 \pm 10.58^{b}$ & $48.62 \pm 0.30^{b}$ & $85.62 \pm 0.53$ & $1.77 \pm 0.02^{\mathrm{a}}$ & 100 \\
\hline & 600 & $193.00 \pm 0.63$ & $1880.67 \pm 13.37^{\mathrm{bc}}$ & ${ }^{c} 48.22 \pm 0.38^{\mathrm{bc}}$ & $84.99 \pm 0.67$ & $1.77 \pm 0.02^{\mathrm{a}}$ & 93.33 \\
\hline & 900 & $192.67 \pm 0.99$ & $1857.50 \pm 11.31^{\mathrm{c}}$ & $47.57 \pm 0.34^{\mathrm{c}}$ & $84.01 \pm 1.14$ & $1.77 \pm 0.03^{\mathrm{a}}$ & 100 \\
\hline \multicolumn{2}{|c|}{ Interaction } & NS & NS & NS & $*$ & NS & \\
\hline & 0.0 & $193.00 \pm 1.00$ & $1955.00 \pm 08.66$ & $50.34 \pm 0.25$ & $85.98 \pm 0.33$ & $1.71 \pm 0.01$ & 93.33 \\
\hline \multirow[t]{4}{*}{0.0} & 300 & $192.67 \pm 1.20$ & $1878.33 \pm 13.64$ & $48.16 \pm 0.41$ & $86.14 \pm 0.93$ & $1.80 \pm 0.02$ & 100 \\
\hline & 600 & $193.00 \pm 1.00$ & $1855.00 \pm 12.58$ & $47.48 \pm 0.35$ & $86.11 \pm 0.64$ & $1.82 \pm 0.01$ & 93.33 \\
\hline & 900 & $192.67 \pm 2.03$ & $1845.00 \pm 08.66$ & $47.21 \pm 0.30$ & $86.42 \pm 0.79$ & $1.83 \pm 0.02$ & 100 \\
\hline & 0.0 & $193.00 \pm 2.52$ & $1997.33 \pm 11.85$ & $51.55 \pm 0.40$ & $84.18 \pm 0.56$ & $1.63 \pm 0.02$ & 100 \\
\hline \multirow[t]{3}{*}{0.5} & 300 & $193.00 \pm 1.00$ & $1910.67 \pm 10.59$ & $49.08 \pm 0.28$ & $85.09 \pm 0.53$ & $1.74 \pm 0.03$ & 100 \\
\hline & 600 & $193.00 \pm 1.00$ & $1906.33 \pm 08.76$ & $48.95 \pm 0.23$ & $83.86 \pm 0.77$ & $1.72 \pm 0.02$ & 100 \\
\hline & 900 & $192.67 \pm 0.88$ & $1870.00 \pm 20.21$ & $47.92 \pm 0.59$ & $81.60 \pm 0.27$ & $1.71 \pm 0.03$ & 100 \\
\hline
\end{tabular}

Means in the same column within each classification bearing different letters are significantly different.

$* *(\mathrm{P} \leq 0.01), \quad *(\mathrm{P} \leq 0.05)$ and $\mathrm{NS}=$ Not significantly

significantly $(\mathrm{p}<0.01)$ impaired, while daily feed intake insignificantly affected due to lead supplementation (Table 2). It is clear that, the impared in LBW, BWG and feed conversion ration were increased with lead supplementation increased. The reduction of body weight might be due to the interruption in absorption and metabolism of feed nutrients essential for health (Marchlewicz et al., 2007). In this respect, Erdogan et al. (2005) found that dietary treatment with lead acetate significantly $(\mathrm{P}<0.05)$ decreased body weight of broiler chicks.
All growth performance traits presented in Table 2 were not affected significantly by the interactions between dietary garlic and lead acetate levels except daily feed intake was significantly $(\mathrm{P}<0.05)$ affected (Table 2$)$. These results suggested that the addition of garlic powder to broiler diets tended to reverse the inhibitory effect of lead intoxication on growth performance of broiler chicks.

\section{Carcass Traits}

The results presented in Table 3 show that giblets percentage was significantly $(p<0.01)$ decreased due to garlic and lead acetate 
Table 3. Carcass traits of broiler chicks as affected by dietary supplementation with lead acetate, garlic powder and their interactions at week 6 of age

\begin{tabular}{|c|c|c|c|c|}
\hline \multicolumn{2}{|l|}{ Item } & Carcass (\%) & Giblets (\%) & Dressing (\%) \\
\hline \multicolumn{2}{|c|}{ Dietary garlic levels (g/kg diet) } & NS & $* *$ & $\mathrm{NS}$ \\
\hline & $\mathbf{0 . 0}$ & $76.47 \pm 0.58$ & $4.20 \pm 0.11$ & $80.67 \pm 0.58$ \\
\hline & 5.0 & $76.17 \pm 0.67$ & $3.93 \pm 0.08$ & $80.09 \pm 0.67$ \\
\hline \multicolumn{2}{|c|}{ Lead acetate levels (mg/kg diet) } & NS & $* *$ & NS \\
\hline & $\mathbf{0 . 0}$ & $74.79 \pm 0.73$ & $4.38 \pm 0.15^{\mathrm{a}}$ & $79.17 \pm 0.76$ \\
\hline & 300 & $76.25 \pm 1.21$ & $3.88 \pm 0.13^{\mathrm{b}}$ & $80.12 \pm 1.21$ \\
\hline & 600 & $76.88 \pm 0.61$ & $4.01 \pm 0.15^{\mathrm{b}}$ & $80.89 \pm 0.71$ \\
\hline & 900 & $77.36 \pm 0.59$ & $3.99 \pm 0.07^{\mathrm{b}}$ & $81.35 \pm 0.61$ \\
\hline \multicolumn{2}{|c|}{ Interaction } & NS & NS & NS \\
\hline & $\mathbf{0 . 0}$ & $75.34 \pm 0.83$ & $4.61 \pm 0.17$ & $79.95 \pm 0.79$ \\
\hline \multirow[t]{4}{*}{0.0} & 300 & $75.24 \pm 1.32$ & $3.94 \pm 0.26$ & $79.18 \pm 1.30$ \\
\hline & 600 & $77.95 \pm 0.61$ & $4.32 \pm 0.02$ & $82.27 \pm 0.58$ \\
\hline & 900 & $77.36 \pm 1.26$ & $3.94 \pm 0.09$ & $81.29 \pm 1.34$ \\
\hline & $\mathbf{0 . 0}$ & $74.24 \pm 1.28$ & $4.16 \pm 0.20$ & $78.39 \pm 1.30$ \\
\hline \multirow[t]{3}{*}{0.5} & 300 & $77.26 \pm 2.13$ & $3.81 \pm 0.13$ & $81.07 \pm 2.18$ \\
\hline & 600 & $75.81 \pm 0.60$ & $3.69 \pm 0.14$ & $79.50 \pm 0.53$ \\
\hline & 900 & $77.36 \pm 0.35$ & $4.04 \pm 0.12$ & $81.41 \pm 0.24$ \\
\hline
\end{tabular}

Means in the same column within each classification bearing different letters are significantly different.

$* *(\mathrm{P} \leq 0.01)$ and $\mathrm{NS}=$ Not significantly.

supplementation in the diet comparable to control group. Carcass and dressing percentages were insignificantly affected by dietary supplementation with garlic or lead acetate levels. Carcass parameters were not significantly affected by the interactions between dietary garlic and lead acetate supplementation (Table 3). Dieumou et al. (2012) reported that garlic organic extract had insignificantly effects on dressing percentage but they all had better values than those on the control.

\section{Conclusion}

Results obtained suggested that garlic supplementation at $0.5 \%$ in broiler chick diets can promotes growth performance traits and tended to reverse the inhibitory effects of lead intoxication on such traits.

\section{REFERENCES}

Amagase, H., B.L. Petessch, H. Matsuura, S. Kasuga and Y. Itakura (2001). Intake of garlic and its bioactive compounds. J. Nutr., 131: 955S-962S.

Aziz, A.A., R.H. Majeed and A.A. Muhammad (2016). Effect of adding different levels of garlic powder to diets on broiler performance. Iraq. Poult. Sci. J., 10 (1): 70-82.

Ashour, A. (2002). Can garlic lobes, olive oil or black seed oil offer protection for some serum biochemical constituents against lead toxicity in rabbits. Al-Aqsa Univ. J., 6:74-95.

Bakalli, R.I., G.M. Pesti and W.L. Ragland (1995). The magnitude of lead toxicity in broiler chickens. Vet. Human Toxicol., 37: 15-19. 
Dieumou, F.E., A. Teguia, J.R. Kuiate, J.D. Tamokou, U.D. Doma, U.S. Abdullahi and A.E. Chiroma (2012). Effect of diets fortified with garlic organic extract and streptomycin sulphate on growth performance and carcass characteristics of broilers. Int. J. Livestock Prod., 3 (4): 36-42.

Duncan, D.B. (1955). Multiple Range and Multiple F Tests. Biometrics, 11: 1-42.

Erdogan, Z., S. Erdogan, T. Aksu and E. Baytok (2005). The effect of dietary lead exposure and ascorbic acid on performance, lipid peroxidation status and biochemical parameters of broilers. Turkey J. Vet. and Anim. Sci., 29: 1053-1059.

Fadlalla, I.M.T., B.H. Mohammed and A.O. Bakhiet (2010). Effect of feeding garlic on the performance and immunity of broilers. Asian J. Poult. Sci., 4 (4): 182-189.

Gurer, H. and N. Ercal (2000). Can antioxidants be beneficial in the treatment of lead poisoning? Free Radical Biol. and Med., 29: 927-945.

Genevieve, D. and J.H. Greg (1994). Toxins. In: Avian Medicine: Principles and Application. (WRBranson, JH Greg nad RH Linda, editors) Wingers Publishing, Inc., Lake Worth, Florida, 1030-1051.

Heaney, R.P. (2000). Lead in calcium supplements. J. Ame. Med. Assoc., 284: 1432-1433.

Hossain, M.A., M.R. Akanda, M. Mostofa and M.A. Awal (2014). Ameliorative effects of dried garlic powder (Allium sativum) on hematological parameters against lead $(\mathrm{Pb})$ intoxication in broiler chickens (2014). J. Adv. Vet. and Anim. Res., 5 (3): 110-119.

Khan, M.S.H., M. Mostofa, M.S. Jahan, M.A. Sayed and M.A. Hossain (2008). Effect of garlic and Vitamamin-B complex in lead acetate induced toxicities in mice. Bangladesh J. Vet. Med., 6 (2): 203-210.

Mahaffy, K.R. and J.E. Vanderveen (1979). Nutrient-toxicant interaction: susceptible popoulation. Environ. Healthperspect, 12: $75-81$

Marchlewicz, M., B. Wiszniewska, B. Gonet, B.I. Baranowska, K. Safranow, A. Kolasa, W. Glabowski, R. Kurzawa, K. Jakubowska and M.E. Rac (2007). Increased lipidperoxidation and ascorbic acid utilization in testis and epididymis of mice chronically exposed tolead. Biometals., 20:13-19.

McDowell, L.S. (1992). Minerals in Animal and Human Nutrition. Academic Press Inc., California, 361-364.

North, M. and D. Bell (1990). Commercial Chicken Production Manual (4 ${ }^{\text {th }}$ Ed.). Van NostrandReinhold, New York, NY, 456.

NRC (1994). Nutrient Requirements of Poultry. $9^{\text {th }}$ Ed., Nat. Acad. Press, Washington, DC., USA., ISBN-13: 9780309048927, 155.

Peinado, M., R. Ruiz, A. Echávarri, I. ArandaOlmedo and L. Rubio (2013). Garlic derivative PTS-O modulates intestinal microbiota composition and improves digestibility in growing broiler chickens. Anim. Feed Sci. and Technol., 181 (1-4): 87-92.

SAS (2002). SAS Proprietary Software Version 9.00 (TS M0). SAS Inst. Inc., Cary, NC., USA.

Snedcor, G.W. and W.G. Cochran (1982). Statistical Methods. $6^{\text {th }}$ Ed., Iowa a State University Press, Ames, USA. Tarasewicz, Z., J. Gardz.

Suriya, R., I. Zulkifli and A.R. Alimon (2012). The effect of dietary inclusion of herbs as growthpromoter in broiler chickens. J. Anim. Vet. Adv., 11: 346-350. 


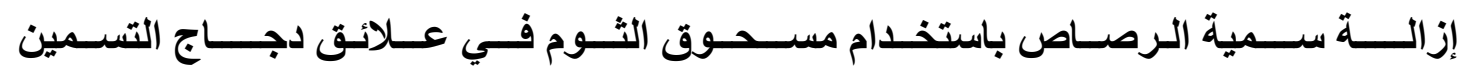

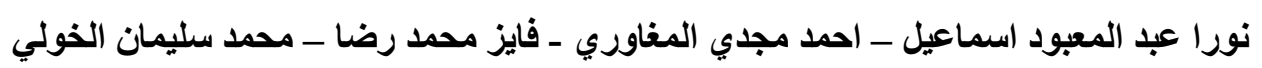

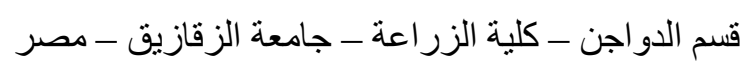

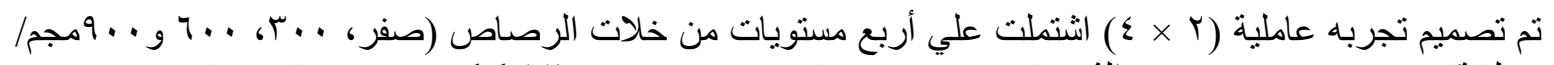

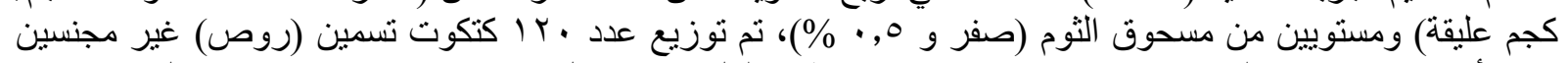

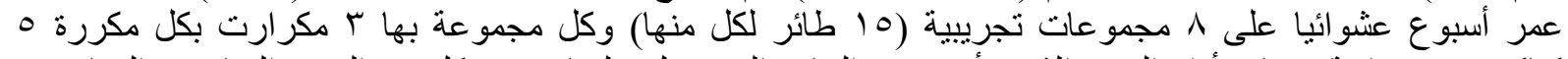

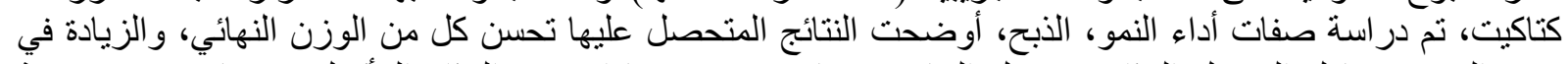

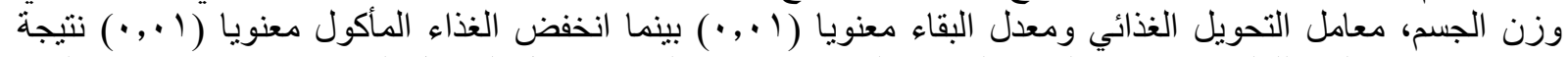

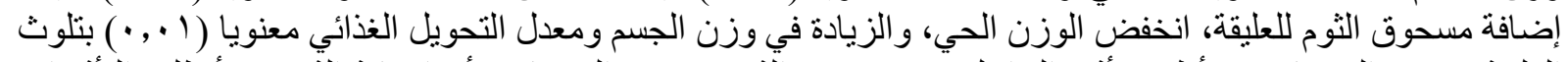

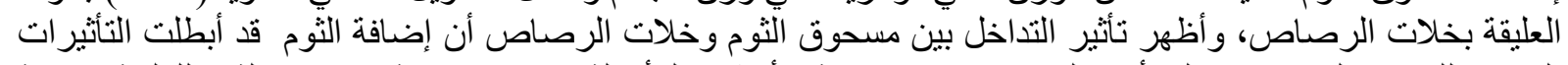

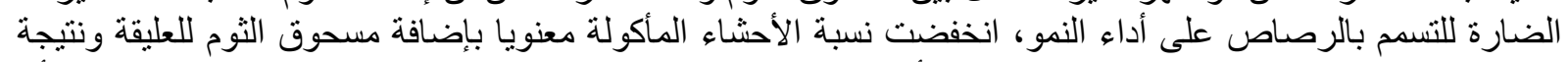

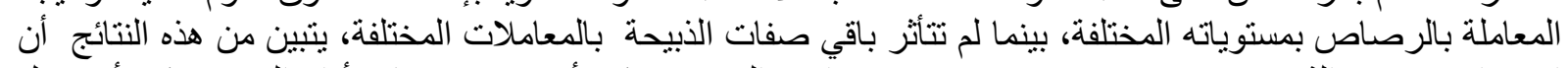

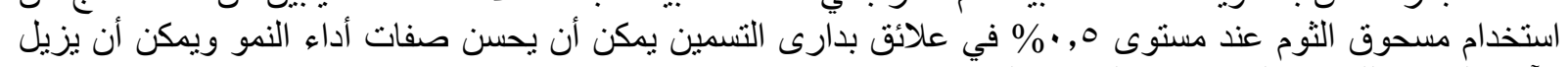
الآثار الضارة للتسمم بالرصاص على هذه الصفات. 